\title{
México de afuera in Northern Missouri: The Creation of Porfiriato Society in America's Heartland
}

\author{
Craig Dennison \\ Westminster College, USA
}

\begin{abstract}
This essay examines the ideology of México de afuera in the novel La patria perdida by Teodoro Torres. Torres, who fled Mexico after the onset of the Mexican Revolution, found a job as lead editor of La Prensa, the successful Spanish-language newspaper owned by Ignacio Lozano. Living in San Antonio during the 1910s, Torres became familiar with the ideology of México de afuera before returning to Mexico. His novel, which begins in northern Missouri, follows the return of Luis Alfaro to his homeland only to discover that he feels more at home, more in Mexico, on his farm north of Kansas City. When studying the work and the life of Torres, the plot of this novel become problematic. A man who lived in the United States for nine years before returning to Mexico, Torres certainly had the insight to provide psychological and emotional analyses of the immigrants and the understanding to write about the thoughts and feelings that many had experienced upon their return to the homeland. Yet, why does Torres, who had returned to Mexico and done well for himself for over a decade before he penned this novel, invent an immigrant utopia on a farm in Missouri? It is not a question that is easily answered, but after examining Torres's life, the basic tenets of México de afuera and the novel itself, a conclusion can be reached. Torres idolized Porfiriato society and Luis Alfaro's farm is an idealized version of fin-de-siècle Mexico.
\end{abstract}

[Key Words: Mexican-American literatura, Mexico de afuera, Teodorro Torres, Immigrant literatura, Porfiriato, Mexican Revolution.]

On the evening that Teodoro Torres, the "Father of Mexican Journalism" (Kanellos 5), was inducted into the Mexican Academy of Letters, the speaker who gave the response to Torres's opening speech, Carlos González Peña, declared to the other members of the academy that Torres was being inducted largely because of one work, La Patria Perdida (102). La patria perdida ("The Homeland Lost") is one of the few novels of Hispanic immigrant literature from the early twentieth century. While dealing with the same themes of Hispanic immigrant literature-the yearning for the patria, the resistance to assimilation-as those found in Las aventuras de don Chipote 0 , cuando los pericos mamen (The Adventures of Don Chipote, or, When Parrots Breastfeed), El sol de Tejas (Under the Texas Sun) and Lucas Guevara, Torres, unlike Daniel Vanegas, Conrado Espinosa or Alirio Díaz Guerra, had returned to his homeland, Mexico, before the publication of his masterpiece and was able to incorporate a different perspective in his novel. While the novels mentioned above focus on the difficulties that immigrants face as they come the United States to find wealth or success, La patria perdida is able to tell the story of an immigrant who returns to Mexico only to discover that he feels more at home on the farm he has established in northern Missouri. ${ }^{i}$ This is not, however, the tale of an immigrant acclimating to life in America. Luis Alfaro, the protagonist, misses the Mexico where he spent his youth and cannot adjust to the ways of the Americans or the European immigrants with whom he occasionally interacts. Instead, he creates a pseudo-colony on his large ranch, a colony that, in his mind, has

Rupkatha Journal on Interdisciplinary Studies in Humanities (ISSN 0975-2935), Vol 2, No 3, 2010

URL of the Issue: http://rupkatha.com/v2n3.php

URL of the article: http://rupkatha.com/V2/n3/v2n304.pdf

(c) www.rupkatha.com 
remained more true to Mexico than Mexico itself, a tiny México de afuera (Mexico from the outside).

When studying the work and the life of Torres, the plot of this novel become problematic. A man who lived in the United States for nine years before returning to Mexico, Torres certainly had the insight to provide psychological and emotional analyses of the immigrants and the understanding to write about the thoughts and feelings that many had experienced upon their return to the homeland, if they were able to do so. Yet, why does Torres, who had returned to Mexico and done well for himself for over a decade before he penned this novel, advocate the ideology of México de afuera on a farm in Missouri? It is not a question that is easily answered, but after examining Torres's life, the basic tenets of México de afuera and the novel itself, a conclusion can be reached. Torres was nothing less than an ardent supporter of the Porfiriato (Mexican society during the age of Porfirio Diaz) and Luis Alfaro's farm is a mini-creation of the society from that era of Mexico in which the poor, landless peasants happily (at least in the novel) work for their generous landowner.

\section{Torres's Early Life and the Porfiriato}

Torres was born in 1891, at the height of the Porfiriato, in a small town in San Luis Potosí, Villa de Guadalupe (Ocampo de Gómez and Prado Velázquez 379). Porfirio Díaz, one of the heroes of the Battle of Puebla, had already won the presidency for the first time in 1876 and then reclaimed leadership in 1881. Many of the Mexican financial and intellectual elite supported Díaz's regime as the country's economy grew with the aid of both domestic and foreign financiers who saw enormous returns-ten to fifteen percent-on their investments during the late 1880s and 1890s. Modernization swept over the countryside as workers laid thousands of miles of railroad tracks and installed telegraph and, afterwards, telephone lines (Kirkwood 122-23). Large haciendas thrived as they swallowed up swaths of land that had belonged to peasant farmers for generations. This growth came at a cost, however, and many of the elite simply were unaware of or disregarded the suffering of the lower classes.

The Díaz regime permitted private citizens and companies to survey the land before the construction of the railroads and, if no one possessed a legal document that demonstrated ownership of the land, those companies or individuals were entitled to keep one-third of the land while the government sold the rest at auctions. Thus, peasants whose families had been working and living on the land for decades or centuries often found themselves homeless because they did not possess a legal deed to the land. Meanwhile, the latifundios (large rural estates) were expanding at an alarming rate. Entire towns disappeared as the haciendas grew and either consumed the villages or devoured the local water supply for their own needs. The economic success that Mexico experienced during the Porfiriato often left the poor homeless and powerless. The discontent that amassed during the later years of the Díaz's reign would erupt violently in the Mexican Revolution. 
This was the environment in which Torres spent his youth. His feelings about that era become readily apparent when reading La patria perdida. Luis Alfaro has many nostalgic moments during which he yearns for the Mexico of his adolescence where he roamed the verdant countryside and wooed beautiful maidens. His only memories of the peasants and their landowners, his family, are those surrounded by contentment. During his journey to Patzcuaro-the welcoming town where he spent his youth-Alfaro experiences a noche oscura del alma (dark night of the soul) during which he relives not only his personal history, but also the glorious history of Michoacán (278-85). Patzcuaro, the lake and Janitzio have remained unspoiled. The land is still pure. The politicians, the revolutionaries and those citizens who allowed their nation to be corrupted without fighting back are the ones who are tainted.

Indeed, Torres does celebrate fin-de-siècle Mexican society in La patria perdida, but he depicts the Porfiriato in an even more idealized manner in his last novel, Golondrina ("The Swallow"). Published posthumously in 1944 , it is another novel about migration. In this story Torres describes how the upper and middle classes abandon a town which he simply calls Villaprobably Villa de Guadalupe in San Luis Potosí where he was born-while revolutionaries and politicians move in and establish control. The first part of the novel, entitled "El campo," takes place during the end of the Porfiriato when "El campo olía a gloria" (9) ("The countryside smelled of heaven"). Rain, a symbol in the novel of the Porfiriato, comes over the town and helps the land to flourish. Like Díaz, the rain brings calm and nutrients to a land that had seen so many hazards. It will be a fruitful year and all the townspeople are content with their lot in a little village where everyone knows everyone else. The only people who are disgruntled are so because they choose to be. They opt to either drink or remain idle instead of work the land. It is not that life has been unfair to them or that there are not opportunities, it is that they decide to not work the beautiful land that God has bestowed upon them (58).

Porfirio Díaz himself is regarded as "el glorioso general y gobernante" (63) ("the glorious general and leader") by the narrator who considers this Mexico, where the landowners and peasants work in perfect harmony, as a pseudo-utopia. The rain is followed by a drought, symbolizing the Revolution, and everything is quickly destroyed by the violence which comes to their little plot of earth well after it had begun in other parts:

No era que ignoraran que en la frontera del país había una revolución y que por todas partes cundía el temblor de un malestar semejante al cansancio de un pueblo turbulento que ha estado mucho tiempo en la forzada postura de la paz; pero connaturalizados con su pacífica existencia, confiados en la fortaleza de un gobierno que llevaba treinta años de mandar pacíficamente y engañados por su propio contento que les daba la idea de que no podría haber descontentos en el mundo, siempre vieron como un peligro lejano aquel que en Chihuahua y en Morelos había repetido los episodios sangrientos de otros tiempos bien conocidos por todos. (116-17) 
"It wasn't that they ignored that on the country's border there was a revolution and that a tremor of uneasiness similar to the weariness of a turbulent people who had been living in forced peace for a long time was spreading everywhere; but naturalized together in their peaceful existence, trusting in the strength of a government that had been in power peacefully for thirty years and fooled by their own happiness that gave them the idea that there could not be unhappy people in the world, they always viewed as a faraway danger that man who in Chihuahua and in Morelos had repeated the bloody episodes from other times well-known by all."

In this passage the difference between the Porfiriato and the Revolution is clearly delineated. During the Porfiriato, peace reigned (in truth there were many revolts and eruptions of violence that Díaz put down, but Torres ignores this) while the Revolution brought bloody episodes reminiscent of other eras. Díaz's government ruled for thirty peaceful years while the Revolution brought chaos and violence. Even though the Revolution had already begun in other parts of Mexico, the denizens of Villa were so happy that they could not imagine anyone rebelling against a system that brought such contentment. The inhabitants of Villa were like the leaders of the Porfiriato, and probably Torres himself, in that they could not see the suffering of others through their own prosperity. They ignored the swell of discontent until it was too late and, like Torres, they would have to abandon the land they loved.

\section{Immigration and the Mexican Revolution}

There have been waves of immigration from Mexico to the United States since gold was found in California after the Mexican-American War in 1848. The California Gold Rush not only attracted settlers from the Eastern seaboard and Midwest of the United States, but also citizens from Mexico who crossed the border of the new state with relative ease. Even before the discovery of the precious metal at Sutter's Mill in 1848, it is estimated that some 80,000 Mexicans were residing in American territories or states that had, just years before, belonged to Mexico (Rosales 2). The exact number of immigrants that came before 1900 is not known, but citizens in northern Mexico certainly had economic and sometimes familial ties to MexicanAmericans living just across the new boundaries that were established after 1848 and 1853. The larger waves of immigration, however, soon became tied to the economy and a pattern of pull and push was established. When the American economy was doing well, Mexicans would come across the border to work. Often, American companies or private citizens would recruit Mexicans to come work in their factories or on their farms. Then, when the economy would turn sour, the companies and farmers would fire the immigrant laborers who would then try to find other jobs or return to their homeland. This system of pull and push would continue throughout the twentieth century as many immigrants were brought in during the Roaring 20s and then deported in the 1930s with the onset of the Great Depression. The 
only event that would play a bigger role than the economy in the immigration from Mexico was the Mexican Revolution.

The Revolution officially began in Chihuahua under the command of Francisco Madero on November 20, 1910. While most of the major fighting came to an end in May 1920, more rebellions occurred sporadically during the next two decades. It is estimated that more than one million of the fifteen million citizens of Mexico immigrated to the United States Mexico during that time. Thirty years of chaos and change were to follow the thirty-five years of the Porfiriato and Mexico would never be the same (Krauze 241-44).

Torres's view of the Revolution and revolutionaries was one of aversion. In fact, his first book was a biography of Pancho Villa, published in San Antonio by the Casa Editorial Lozano and entitled Pancho Villa: Una vida de romance y tragedia ("Pancho Villa: A Life of Romance and Tragedy"). Torres uses this text not so much to celebrate Villa's life, but rather to condemn its protagonist, other revolutionaries and the Revolution itself. While Torres recognizes that some of the poor laborers respected and followed Villa, and that Villa sometimes showed himself to be intelligent and cunning, he portrays the man himself as a ruthless megalomaniac. The book itself, first published in 1924, one year after Villa's assassination, declares that the public understands that these revolutionaries, these murderers, have to die. It is retribution for the blood on their hands, for ruining Mexico, and Villa deserved his fate more than any other:

La opinión pública ha adoptado una actitud especial cada vez que mira caer a uno de esos tremendos revolucionarios, que mueren aplastados por la propia "máquina loca" que ellos echaron a andar: deplora el derramamiento de sangre, se horroriza con el espectáculo de la tragedia, pide a Dios que cese la matanza de hermanos, pero al mismo tiempo, pensando en esa justicia de los hombres y castiga los crímenes que parecen burlarse de todos los códigos, la opinión pública, repetimos, en lo íntimo de la conciencia de cada ciudadano dice: "tenía que ser." En el caso especial de Francisco Villa, se aceptó con más facilidad el lógico fin del antiguo abigeo durangueño. (233)

"Public opinion has adopted a special attitude each time that it sees one of those terrible revolutionaries fall, who die crushed by the same "crazy machine" that they helped to start: it deplores the spilling of blood, it is horrified by the tragic scene, it asks God to end the killing of brothers, but at the same time, it thinks of justice for those men and it punishes the crimes that seem to mock all laws, public opinion, we repeat, in the most intimate corner of the conscience of each citizens says: "it had to be." In the special case of Francisco Villa, the logical end of the old Duranguense rustler was accepted with more ease."

Here, Torres has inserted his opinion and declared it that of the public. While he tries to cover up his true feelings by declaring that he (the public) deplores the spilling of blood and is horrified by the tragedy, his distaste becomes obvious as he concludes that these men, these revolutionaries, got 
exactly what they deserved, and that Villa's death is easier to understand than the deaths of the others. He does not view these men and their supporters as opponents of discrimination and injustice. No, for Torres, the revolutionaries and the Revolution had merely succeeded in ruining "treinta años de paz bajo el gobierno admirable del General Porfirio Díaz" (81) (thirty years of peace under the admirable government of General Porfirio Diaz).

\section{The Creation of an Ideology for "México de afuera"}

The more than one million immigrants who crossed the border in the early twentieth century created a new identity in the Southwest United States. Americans had come to outnumber the native Mexican population during the nineteenth century in Texas and California (Arizona and New Mexico did not become states until the early twentieth century) and imposed their majority culture throughout those two states. With the rise in immigration in the 1900s and 1910s, however, Mexican-Americans forged an identity and a space for themselves in the Southwest. San Antonio was arguably the first metropolitan center where a distinctly Mexican-American identity formed. It had been an important city during the colonial era as the capital of Tejas and later as the capital of the Mexican province called by the same name. After Texas became part of the United States, Americans and Germans began to migrate to this important city and it established a distinctly tri-cultural atmosphere. As the Mexican immigrants steadily streamed in before, during and after the Revolution, their influence in San Antonio became more and more apparent.

As their numbers grew, these immigrants, many of whom felt that they had been forced to leave their homeland either for economic reasons or because of the violence of the Revolution, began to work in ways which fashioned a new, distinct identity. They did not readily assimilate. Instead, they fought to keep some of their traditions and heritage, to maintain some form of mexicanidad (Rosales 75) (Mexican culture). Movements emerged to help protect the rights of the immigrants who moved to the United States and to ensure that the homeland was not forgotten. The Spanish-language newspapers played important intellectual, cultural and political roles in these movements, often writing about what was occurring in Mexico, providing coverage of events taking place in Mexican-American societies and encouraging their readers not to give up Mexican values. The Spanishlanguage newspapers in San Antonio were fervently pro-Mexican and the most important newspaper there during the Mexican Revolution was La Prensa ("The Press"), ran by Ignacio Lozano.

Lozano had moved to San Antonio in 1908, two years before the onset of the Revolution. His father had died suddenly and his family moved from Durango to San Antonio. He had written a little in his hometown in Mexico, Mapimí, and soon obtained a job working for Adolfo Duclós Salinas (RíosMcMillan 136). After Salinas's death, he got a job working for El Imparcial ("The Impartial"), owned by Francisco Chapa. Completely responsible for the newspaper's publication, Lozano worked for Chapa until 1912. With the invaluable experience he gained working for El Imparcial and a savings of 
$\$ 1,200$, he began his own newspaper. La Prensa was first published in 1913 and, by the end of the year, its circulation increased to 10,000 (137). The record numbers of immigrants coming to San Antonio needed a connection to the homeland they had just left behind and La Prensa provided that link. As Torres himself puts it, "Al lector mexicano le interesaba muy particularmente la información de su país, el telegrama que le hablara de los cambios de la política, que le prometiera restauraciones económicas o sociales y le fuera dando altibajos de la vida pública de importantes personalidades" (La Patria Perdida 172) ("The Mexican reader was particularly interested in information about his country, the telegram that spoke to him about the changes in the politics, that promised him economic or social restorations and was giving him the highs and lows of the public life of important people"). With updates on the war, news about political events and stories that honored the history of their nation, the newspaper became wildly popular among the working-class immigrants in San Antonio. Lozano and writers of La Prensa became very influential in Mexican-American communities throughout the Texas and, later on, the rest of the Southwest. As time passed and more and more of the immigrants stayed in America, a new ideology emerged. This ideology came to see the Mexico that they had left behind corrupted. The many politicians and revolutionaries that came and went during the Revolution and afterwards left the country scarred beyond recognition. The men and women behind this ideology viewed the Mexican-American communities that had formed throughout the United States as the true Mexico. They began to refer to these communities as el México de afuera. This term was first mentioned by Rodolfo Uranga in the 1910s to refer to a group of Mexican exiles but later became identified with the Mexican-American communities themselves (Luna Lawhn 85). The men and women who believed in the concept of México de afuera could be found in all spheres of society in San Antonio; business, health, politics and media. One of the main beliefs of the ideology of Mexico de afuera was the importance of returning to Mexico, to a Mexico that would one day be ready to break the chokehold of corrupt politicians and violent revolutionaries. Their ideology came to consist of a strong nationalistic spirit, belief in celebrating national holidays, adherence to Catholicism, veneration of the Virgin of Guadalupe, use of Spanish language, studying Mexican history and the spiritual re-conquest of the Southwest, of territories lost to America during the Mexican-American war (Hinojosa 5-9). They believed that the communities that followed these tenets were purer and truer to Mexico than the Mexico that emerged after the Revolution.

Upon immigrating to the United States, Torres found employment as an editor for La Prensa. Lozano eventually employed many prominent Mexicans and Mexican-Americans on his staff or as contributing writers, such as José Vasconcelos, María Luisa Garza and Querido Moheno, but Torres was one of his first important hires (Kanellos 5). During the 1910s and the early 1920s, Torres mingled with the upper crust of Mexican-American society and became well-acquainted with the ideology of México de afuera. However, Torres also noticed that the México de afuera of San Antonio was not the pure Mexican community that the promoters of the ideology imagined it to be. 
The reader can easily discover Torres's ideas regarding the MexicanAmerican communities in San Antonio because a good part of La patria perdida takes place there. On his way to Mexico, Alfaro stops in San Antonio to meet up with an old friend, Pepe Sarmiento, who is now a journalist working for a Spanish-language newspaper in the Alamo City. They spend time catching up, but quickly the conversation turns to Mexico and the future of her citizenry, both abroad and in the homeland. Alfaro quietly notices that, as much as his friend still has many of the qualities which he admired during his youth, there is a change which troubles him. Sarmiento detects Alfaro's discomfort and brings up the problem that is disturbing him, "Estás asombrado ¿no es cierto? de que todos seamos aquí personajes de viso, señores de vida arrastrada, hombres de pro, gente de automóvil? Pues te encuentras ante el aspecto más seductor de la vida norteamericana" (158) ("You are surprised, isn't it true, that we all here are important characters, gentlemen with wretched lives, noteworthy men, people with cars? Well you find yourself before the most seductive aspect of the American life"). While the Mexican-American community in San Antonio has remained faithful to the homeland in certain aspects-such as retaining their language and love for their country-in other ways they have begun to lose their identity. Both Alfaro and Sarmiento understand that the idea that Mexicans could live in America without adopting some of the customs or lifestyle habits from the majority culture proves to be a fallacy. The United States will inevitably influence in some way the Mexico de afuera communities. The most corrupting influence, in Sarmiento's mind, is the rampant consumerism, yet it is one that he cannot avoid. He knows he has changed since he left Mexico and he will not return. $\mathrm{He}$ is an American, just as many of the creators and promotors of the ideology of Mexico de afuera would become American citizens, and he will not return to Mexico, "Yo soy el primero en reírme, observándome, con lo poco que queda de mí del antiguo Sarmiento, con una subconciencia que muy pocas veces logra levantarse y halla ridícula, dolorosa, la adaptación de un individuo de determinadas condiciones y tendencias, a una vida vaciada en el molde yanqui" (163) (I am the first to laugh, observing myself, with the little that remains in me of the old Sarmiento, with a subconscious that very few times can arise and it finds ridiculous, painful, the acclimation of an individual of determined conditions and tendencies, to a life draining away in a Yankee mold").

Sarmiento may well be a character based on Ignacio Lozano himself. Lozano did not return to Mexico, although he stated often that it was his dream (Ríos-McMillan 141), but rather he would move to Los Angeles and begin another Spanish-language newspaper, arguably the most successful in the history of the United States, La Opinión. Sarmiento, like Lozano, is a good man. Also, like Lozano, he will never return to his homeland. Alfaro comes to understand Sarmiento's perspective, but he refuses to accept it. He continues on to his homeland, knowing that he will never return to San Antonio or see his friend again. 
What Torres is conveying here is that the México de afuera that had been imagined as a successor to pre-Revolution Mexico cannot be found in San Antonio or any other major urban center where large numbers of Mexican citizens lived. It is too easy for their culture to be corrupted by the larger American culture. To return to the Mexico of the late nineteenth or early twentieth century, to the Porfiriato, the only place to go is to the country. Thus, Torres locates his version of Mexico de afuera in America's heartland, in northern Missouri.

\section{Mexico de afuera in Northern Missouri}

In contrast with other novels of Mexican immigration to the United States from the early twentieth century, such as Las aventuras de Don Chipote or El sol de Tejas, La patria perdida does not advocate a return to Mexico. This is because, in part, the author of the novel had experienced the return to Mexico himself before writing the book and, if what happens to Alfaro is any indication, Torres's homecoming is not what he imagined it would be.

Upon his return to his native Michoacán, Luis discovers that all of his old friends and family have disappeared. When he asks the owner of the hotel in which he is staying what happened to the haciendas, she asks him if he is a foreigner (266). With every name he brings up, the owner tells him that the person is either dead or has moved out of town. Later, when he visits two women who he knew during his youth, they describe how all of the prosperous families of the Porfiriato in their area had either died off or relocated during the Revolution (318-20). Alfaro leaves Patzcuaro depressed, knowing that he is more at home at his ranch in Missouri than in his hometown. He will return to the true Mexico, to the little colony he has created at Bella Vista.

Sarmiento himself had noticed how little Alfaro has changed despite his many years in America. When Alfaro asks him where he thinks he has been, Sarmiento replies, "Tú vienes de ese agujero, de ese oasis donde vivías y que me acabas de pintar. Rodeado de gente que sufre tu influencia mexicanista, apenas puedes decir que has habitado la misma nación que yo" (163) ("You come from that hole, from that oasis where you were living and which you just described to me. Surrounded by people who suffer your Mexican influence, you Barkly can tell that you have lived in the same nation as I have"). Alfaro has created a space for himself in America where he can carry on, uncontaminated, the lifestyle he led in Mexico. His Bella Vista is a recreation of the Mexican haciendas of the nineteenth century. Isolated on his farm, he has not experienced the corruption that occurred in Mexico at the hands of the generals, politicians and revolutionaries nor has he been contaminated by the American lifestyle in the way that Sarmiento and the other Mexican-Americans had been in San Antonio. His farm, Bella Vista, is where the true Mexico lives on, and it is a utopian re-creation of the Mexican society of the Porfiriato.

This is best seen in the first several chapters which take place at the ranch on Bella Vista. Ana María, Alfaro's wife, is ill. She is, like the Virgin 
Mary, a symbol of purity and her untainted Mexican soul never fully adjusted to life in a foreign country. The Mexican community that has formed on Alfaro's ranch rallies around her, worried with every breath they take about the state of their ama. Luis and Ana María had only brought one servant with them when they came from Mexico, Gabriela. She is the faithful servant, whose entire world "se reducía a su señora" (20) ("was reduced to her mistress"). She has given her whole life to looking after Ana María, from her birth to her death, and she would gladly serve her mistress rather than occupy herself with any other chore.

The rest of workers who live on Bella Vista are Mexican immigrants who, wandering hopelessly throughout America in search of the jobs they thought would make them rich, are attracted to the community that Luis and Ana María have created.

Todos ellos pertenecían a lo que en México ha dado en llamarse la última clase del pueblo: antiguos vaqueros de haciendas, peones de ínfimas labores, obreros de las ciudades, campesinos que vivieron siempre alejados de la ciudad y en quienes prendió un día la idea de emigrar, atraídos por las noticias de los que habían salido antes y relataban historias fabulosas, de la Jauja lejana donde ofrecían jornales diarios mayores que la paga de una semana en las haciendas, en moneda que valía el doble que la de México y cuyo poder adquisitivo era tremendo porque las cosas costaban diez veces menos que las tiendas de raya que siempre los habían provisto. (22)

"They all belonged to what in Mexico has come to be called the last class of people: old cowboys from the haciendas, pawns of low jobs, workers from the cities, peasants who always driven out from the city and in whom sparked one day the idea to immigrate, attracted by the news from those who had gone beforehand and related fabulous tales, from the faraway paradise where they offered better daily jobs than the wages from one week in the haciendas, in currency that was worth double that of Mexico whose purchasing power was tremendous because the products cost ten times less than the infernal stores that had always supplied them."

Torres, when mentioning the origins of these workers, uses the word hacienda two times. While some of the laborers are recent émigrés who probably came after 1920, most are remnants of the Porfiriato society who either left before or during the war. They feel at home on Bella Vista with other Mexican immigrants because there "en lo espiritual el cambio de país no había ejercido sobre ellos ninguna influencia" (23) ("with regard to their spiritual side the change of country had not exercised over them any influence"). Bella Vista has become a Mexican island in an American sea. They have a kind landowner who desires nothing more than to help them:

Las casas de los colonos-mexicanos todos-eran alegres, distintas de las otras de las de aquellos paisanos que trabajaban sin el aliciente de hallarse en una comunidad agradable y bajo el cuidado vigilante y 
paternal de un hombre de la raza que se había propuesto a ayudar a los suyos al mismo tiempo que trabajaba para sí. (76-77)

"The houses of the colonists-all Mexicans-were happy, distinct from those of their countrymen who worked without the fortune of finding themselves in an agreeable community and under the vigilant and paternal care of a man of their race who had proposed to help his men at the same time as he worked for himself."

The little colony is a replication of a Mexican hacienda from the Porfiriato. The peasants toil happily for the latifundista (landowner) who takes care of their basic needs. It is what they know, what they were used to in Mexico, and they are more content there than their countrymen who work in the cities without the protection of a patrón (master). There, on their little Porfiriato island, while so far away from the country they love, the Mexican immigrants' patriotic fervor and nationalistic spirit grow stronger than they had been in their homeland. They openly show their pride in their heritage and adorn their houses with images of the Virgen de Guadalupe, Mexican flags, guitars and washing bowls from Olinalá (76). Luis has created a little Mexico for them north of Kansas City, and they love this little community so much it is as if they had never left Mexico.

Still, they understand that they are not in their homeland. The celebrations and national holidays are marked with emotions that are twice as strong as those they had experienced when celebrating the same festivals or religious days in Mexico. It is during one of these celebrations that Torres most strongly promotes the ideology of México de afuera. The bands are playing, liquor has been smuggled in and the yearning for the homeland is at its height. That is when all the peasants, and the landowners too, realize that while their little colony has brought them prosperity, they are merely biding their time there, until one day when they return to save Mexico, to bring the culture that they had kept pure and intact on their little island in America back to the Mexico that had been spoiled by its corrupt leaders.

Porque para muchos de aquellos pobres campesinos que solo conocieron de su país la miseria y la tiranía, la explotación de los "patrones" y la voracidad de los políticos, la patria se les revelaba allá afuera, como una madre a la que nunca conocieran, a la que nunca vieran y que así, a la distancia se precisaba con los contornos vagos y dulces de una deidad prometedora. Cuando ellos volvieran sería otra cosa. Ya habían aprendido a verla. (119-20)

"Because for many of those poor peasants that had only found poverty and tyranny in their country, the exploitation of the "bosses" and the ferocity of the politicians, the homeland was revealed to them out there, like a mother who they never knew, who they never saw and so who, at a distance was formed with the vague and contours of a promising deity. When they returned it would be another thing. They had already learned to see her." 
The words are telling. When they return, the patria will be different. They will make it different because they have been able to study it from afar and can better detect and understand its flaws. This text is the foundational novel of the ideology of México de afuera. There is a fervent pride in their identity and celebration of their customs. Yet, because of their experiences, which took them out of Mexico, like Torres himself, they better understand both Mexico and its culture. They have retained both in their hearts from a distance while Mexico has been corrupted back home. When they return, they will return with the true Mexico and bring it back to the homeland. All this they learned while living on a litte Porfiriato-style colony in the northwest of Missouri.

\section{Note}

' Some scholars, such as Richard Griswold del Castillo, have suggested that Bella Vista is located in Kansas. While it is located outside Kansas City-which is located in both Missouri and Kansas-a careful reading shows that it is in fact in Missouri, although close to the Kansas border: "Con lo que pudo reunir de los maltrechos bienes de ambos, vendidos a cualquier precio por medio de un procurador voraz, compró Luis unas tierras en el Estado de Missouri, casi en los límites de Kansas, a unas cuantas millas de la importante Kansas City y a un paso del poblado de Arley" (15-16).

\section{Bibliography}

Gamio, Manuel. Mexican Immigration to the United States. Chicago: University of Illinois Press, 1930.

González Peña, Carlos. "Discurso del Académico de Número, Señor don Carlos González Peña." Humorismo y sátira. México D.F.: Editora Mexicana, 1943. 101-11.

Griswold del Castillo, Richard. "Mexican Intellectuals' Perceptions of Mexican-Americans and Chicanos, 1920-present." Aztlan 27.2 (2002): 33-74.

Hinojosa, Fredérico Allen. El México de Afuera y su reintegración a la patria. San Antonio: Artes Gráficas, 1940.

Kanellos, Nicolás. "Recovering and Re-constructing Early Twentieth-Century Hispanic Immigrant Print Culture in the US." American Literary History 19.2 (2007): 1-18.

Kirkwood, Burton. The History of Mexico. Westport, CT: Greenwood Press, 2000.

Krauze, Enrique. Mexico: Biography of Power. Trans. Hank Heifetz. New York: Harper Collins, 1997.

Ocampo de Gómez, Aurora M. and Ernesto Prado Velázquez, eds. "Teodoro Torres." Diccionario de escritores mexicanos. México: UNAM/Centro de Estudios Literarios, 1967. 379.

Ríos-McMillan, Nora. "A Biography of a Man and His Newspaper." The Americas Review 17.3-4 (1989): 136-49.

Rosales, F. Arturo. Chicano. Houston: Arte Público Press, 1996.

Torres, Teodoro. Golondrina. México D.F.: Editora Mexicana, 1944.

--- La patria perdida. México D.F.: Ediciones Botas, 1935.

---. Pancho Villa: Una vida de romance y tragedia. San Antonio: Casa Editorial Lozano,1924.

Craig Dennison is an Assistant Professor of Spanish at Westminster College in Fulton, Missouri. Email: Craig.Dennison@westminster-mo.edu 